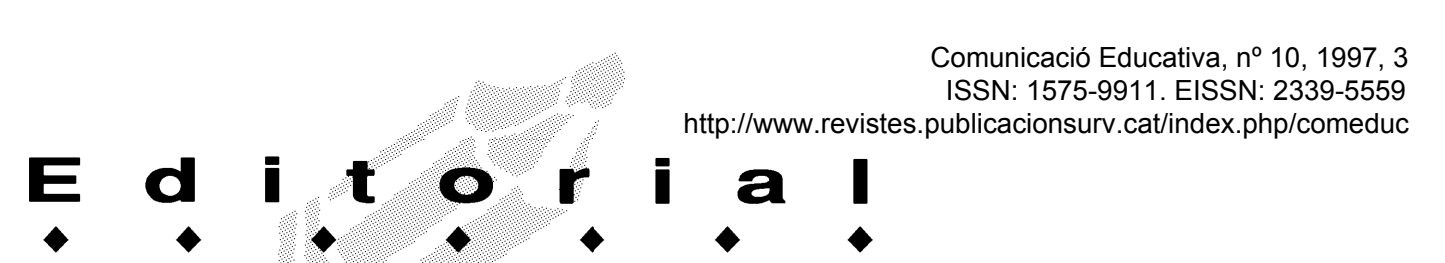

\title{
NOVAMENT, LA LLENGUA CATALANA
}

En aquests moments, en què les forces polítiques del Parlament de Catalunya estan discutint un nou text legal que vagi més enllà de la Llei de Normalització Lingüística del 1983, és bo que des dels centres de formació de mestres ens preguntem com veiem la situació en aquests darrers anys. Una efemèride concreta, la celebració dels deu anys de la revista Interaula -que aplega els formadors de mestres dels Països Catalans- pot resultar també un bon motiu per fer balanç.

Des del nostre col-lectiu de formadors observem una sèrie de característiques que defineixen el sentit i l'orientació d'un panorama molt concret: la procedència socioeconòmica de l'alumnat actual, amb una major presència que als anys 80 d'estudiants d'origen familiar no-catalanoparlant; un millor grau de coneixement acadèmic de la Ilengua catalana, no acompanyat d'actituds de major motivació i interès formatiu per la tasca normalitzadora; un cert clima de cansament i desànim entre el professorat més clarament convençut, a la vista dels resultats poc satisfactoris del seu treball, especialment entre molts dels seus col-legues, que no han progressat gran cosa en aquests darrers anys, més enllà d'uns limitats esforços inicials per normalitzar-se; una excessiva confiança acrítica en la idoneïtat de les mesures oficials de la política lingüística duta a terme a la universitat -usos administratius, serveis de formació, d'assessorament-; i consegüentment, una sensació prou estesa que entre nosaltres ja no cal fer gran cosa més, i que en tot cas deuen ser altres àmbits, citats tòpicament -el comerç, la justícia, els mitjans de comunicació...- els que han de canviar encara els seus comportaments.

A aquest panorama específic, cal afegir-hi altres trets més generals, també molt preocupants: el progressiu empobriment dels usos lingüístics orals i escrits de la població; la pèrdua d'exigència universitària en els rendiments lingüístics entre professors i alumnes; la poca atenció individualitzada als processos formatius dels nostres futurs mestres -fluïdesa oral, riquesa i varietat lèxica, domini escrit del llenguatge, aprofundiment en les lectures i en el coneixement literari, solidesa en la formació didàctica, aprofitament en les pràctiques escolars-; i finalment, un cert clima advers al reconeixement del valor de l'esforç i de l'estudi, a canvi d'una sacralització de la vida fàcil, "divertida".

Per aquí poden anar algunes de les claus en l'observació de les deficiències que cal corregir per tal que el mestre que formem per al futur a casa nostra sigui un professional lingüísticament més ben preparat. Així contribuirem a refer críticament un servei que necessita adaptacions constants per respondre al que l'escola li demana. 